\title{
Changes in the nutrient and anti-nutrient content of micro-fungi fermented cassava flour produced from low- and medium-cyanide variety of cassava tubers
}

\author{
Oboh, G. ${ }^{1 \star}$ and Elusiyan, C. A. ${ }^{2}$ \\ ${ }^{1}$ Biochemistry Department, Federal University of Technology P. M. B. 704 Akure, Nigeria. \\ ${ }^{2}$ Chemistry Department, Federal University of Technology P. M. B. 704 Akure, Nigeria.
}

Accepted 5 March, 2007

\begin{abstract}
Comparative studies were carried out on the ability of pure strain of Rhizopus oryzae and Saccharomyces cerevisae to alter the nutritional quality of cassava flour produced from low- and medium-cyanide variety of cassava tuber. Low- and medium-cyanide variety of cassava tubers were collected from International Institute of Tropical Agriculture (IITA), Ibadan, Nigeria. These tubers were washed, peeled, grated and aseptically inoculated with pure strains of $R$. oryzae and $S$. cerevisae in nutrient solution, independently, before allowing them to ferment aerobically for 3 days. The fermented mash was subsequently dried and milled into cassava flour. Subsequently, the proximate, mineral and the anti-nutrient composition of the cassava flour were determined. The results of the study revealed that the unfermented flour from low-cyanide cassava variety had higher protein, fibre, ash, fat, $\mathrm{Ca}, \mathrm{Na}$ and $\mathrm{K}$ contents, while those produced from medium-cyanide variety, had higher anti-nutrient (tannin, cyanide and phytate), $\mathrm{Zn}, \mathrm{Mg}$ and Fe contents. However, solid substrate fermentation of the cassava mash using $R$. oryzae and $S$. cerevisae, independently, caused a significant $(P<0.05)$ increase in the protein and fat content. The nutrient enrichment was significantly higher $(P<0.05)$ in flour produced from low-cyanide cassava variety. In addition, $S$. cerevisae fermentation brought about a higher increase in the nutrient content than $R$. oryzae fermentation. Conversely, fermentation of the cassava caused a significant decrease $(P<0.05)$ in the anti-nutrient content of the flour; although, the level of decrease was more in the flour produced from low-cyanide variety than medium-cyanide variety. Nevertheless, there was no significant difference $(P>0.05)$ in the ability of the fungi to decrease the antinutrient (except phytate) of the cassava flour. Furthermore, micro-fungi fermentation did not cause a significant change $(P>0.05$ ) in mineral content (except $\mathrm{Mg}$ and $\mathrm{K})$ of the fermented cassava flour. Therefore, unfermented cassava flour produced from low-cyanide cassava tubers had high nutrient composition and low anti-nutrient content, and more susceptible to micro-fungi nutrient enrichment and detoxification than medium-cyanide variety. Furthermore, $S$. cerevisae was more efficient in the nutrient enrichment of the cassava flour than $R$. oryzae.
\end{abstract}

Key words: Cassava, Cyanide, fermentation, nutrient, anti-nutrient.

\section{INTRODUCTION}

Cassava (Manihot esculanta, Crantz) is a good famine relief crop that is eaten by all classes of people. The crop has become widespread and assumed its current imporance as a food during the $20^{\text {th }}$ Century. It is a root tuber plant and a latex producing plant, which reaches a height

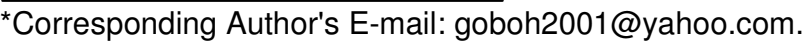

of $1.8-2.6 \mathrm{~m}$ depending on variety. It is also a crop of lowland tropics and it does well in a warm climate where the mean temperature ranges are $25-29^{\circ} \mathrm{C}$ and rainfall is about $100-150 \mathrm{~cm}$ per year (Onwueme, 1978). The advantage it has over other root crops include its propagation, high yields, pest and drought resistance (O'Brien et al. 1991). Cassava have two main types, they are the sweet types that are commonly grown in West Africa and the bitter type. Certain variety especially bitter cassava 
contains large amount of cyanogenic glycosides, which can be hydrolyzed to hydrocyanic acid $(\mathrm{HCN})$ by the endogenous enzyme linamarase when the plant tissue is damaged during harvesting, processing or other mechanical processes (Oboh et al., 2002; Oboh and Akindahunsi, 2003).

Cassava can be used for so many purposes and before it can be used, it should be processed (Oboh and Akindahunsi, 2003). The tuber is processed into garri, tapioca and cassava flour for human consumption, while the leaves are cooked and eaten especially in Sierra Leone and Liberia. Sweet cassava tuber can also be eaten boiled, while the flesh of the tuber can be fed raw or boiled for pigs, goats, horses and cattle. The main industrial use of cassava is in the manufacture of starch and alcohol (Amutha and Gunasekaran, 2001). Cassava is often considered an inferior food because the storage root is low in protein, essential minerals and vitamins. However, in many cassava-growing areas, its use as food helps to alleviate problem of hunger and carbohyrate intake deficiency and thus its importance in terms of food security in these areas cannot be overemphasized.

Two principal methods are available for increasing the protein content of fermented cassava products. The first method involves adding protein to the deficient food from external sources in such a way as not to alter significantly the organoleptic qualities of the original food (Oshodi, 1988; Collins and Falasinnu, 1977; Odetokun et al., 1998). The second, through controlled fermentation, micro-flora could be made in large numbers in the mash (Vlavonou, 1988; Santos and Gomez, 1977). Fermentation is one of the oldest applied biotechnologies, having been used in food processing and preservation as well as beverages production for over 6,000 years (Motarjemi, 2002).

The fermentation process of staples serves as a means of providing a major source of nourishment for large rural populations, and contributes significantly to food security by increasing the range of raw materials, which can be used in the production of edible products (Adewusi et al., 1999). Fermentation enhances the nutrient content of foods through the biosynthesis of vitamins, essential amino acids and proteins, by improving protein quality and fibre digestibility. It also enhances micronutrient bioavailability and aids in degrading anti-nutritional factors (Achinewhu et al., 1998). This method of upgrading the protein content of cassava had been developed in some countries. Solid media fermentation of cassava products is presently practiced in Canada where Aspergillus fumigatus was used (Reade and Gregory, 1975), in Burundi (Vlavonou, 1988) and Nigeria (Akindahunsi et al., 1999) where Rizopus oryzae was used in enriching cassava products with proteins. Recently, Oboh and Akindahinsi (2003) reported that Saccharomyces cerevisae (10.5\%) could also be used for enriching cassava products.

This study is a continuation of our study on nutrient enrichment and detoxification of cassava products using cheap, non-pathogenic saprophytic fungi. In this present study, the nutrient and anti-nutrient content of fermented and unfermented cassava flour from low-and mediumcyanide cassava tuber was assessed. Moreover, this study determines how varietals difference in cassava in terms of cyanide levels will affect the nutrient enrichment of cassava products using $R$. oryzae and $S$. cerevisae solid substrate fermentation technology.

\section{MATERIALS AND METHODS}

\section{Materials}

Low- and medium- cyanide variety of cassava tubers were collected from International Institute of Tropical Agriculture, Ibadan, Nigeria. The chemicals used were of analytical grade, and glass distilled water was used. The fungi $(R$. oryzae and $S$. cerevisae) used were collected from Federal Institute of Industrial Research Oshodi (FIIRO), Lagos, Nigeria.

\section{Sample preparation}

Three treatments were carried out in three replicates each. In the first and second treatment, whole roots were peeled, washed, grated, after which $100 \mathrm{~g}$ of the processed pulp was spread in a tray (about $50 \mathrm{~cm}$ diameter) to an average layer thickness of $2 \mathrm{~cm}$. A $0.5 \mathrm{~g}$ freshly sub-cultured pure strains of either $S$. cerevisae or $R$. oryzae in $73 \mathrm{ml}$ nutrient solution (containing urea $(8.0 \mathrm{~g}), \mathrm{MgSO}_{4}$ $.2 \mathrm{H}_{2} \mathrm{O}(7.0 \mathrm{~g}), \mathrm{KH}_{2} \mathrm{PO}_{4}(1.3 \mathrm{~g})$ and citric acid $(2.0 \mathrm{~g})$ was carefully added to the solid matrix in order to obtain a well homogenized mixture. The mash was allowed to ferment for three days; the incubation temperature and the relative humidity of the air were $30^{\circ} \mathrm{C}$ and $90-93 \%$. The third treatment was the unfermented cassava mash, which serves as the control. After, the fermentation, both the fermented and unfermented cassava mash was sun-dried and milled into cassava flour see Figure 1 (Oboh et al., 2002).

\section{Sample analysis}

The nutrient composition (ash, fat, carbohydrate and crude fibre) of the fermented and unfermented cassava flour were determined using the standard AOAC (1990) method and the protein content was determined using the micro-Kjeldahl method. The phytate content was determined by the method of Wheeler and Ferrel (1971) based on the ability of standard ferric chloride to precipitate phytate in dilute $\mathrm{HCl}$ extracts of the vegetables. The cyanide contents of the fermented and unfermented cassava flour were determined by the procedure as described by De Bruijn (1971). While the tannin content was determined using the method of Makkar et al. (1993). The mineral namely $\mathrm{Ca}, \mathrm{Mg}, \mathrm{Fe}$ and $\mathrm{Zn}$ contents were determined on aliquots of the solutions of the ash by established flame atomic absorption spectrophotometry procedures using a Perkin-Elmer atomic absorption spectrophotometer (model 372) (Perkin-Elmer, 1982), while $\mathrm{Na}$ and $\mathrm{K}$ were determined using flame photometer. Calculation of (phytate) / ( $\mathrm{Zn}),(\mathrm{Ca}) /$ (phytate) and (Ca) (phytate) / $(\mathrm{Zn})$ molar ratios were used in the prediction of $\mathrm{Zn}$ bioavailability in the unfermented and fermented cassava flour (Fergusson et al., 1988).

\section{Data analysis}

The results of the three replicates were pooled and expressed as mean \pm standard error (S. E.). A one-way analysis of variance 
Table 1. Proximate composition of micro-fungi fermented cassava flour (\% dry weight).

\begin{tabular}{|c|c|c|c|c|c|}
\hline Sample & Protein & Crude fibre & Ash & Fat & Carbohydrate \\
\hline \multicolumn{6}{|l|}{ Low-cyanide } \\
\hline $\begin{array}{l}\text { Unfermented } \\
\text { Fermented }\end{array}$ & $6.4 \pm 0.5^{b}$ & $3.8 \pm 0.4^{d}$ & $1.4 \pm 0.3^{\mathrm{a}}$ & $2.9 \pm 0.5^{b}$ & $85.5 \pm 2.0^{b}$ \\
\hline R. oryzae & $10.5 \pm 0.2^{\mathrm{e}}$ & $1.9 \pm 0.1^{a}$ & $2.6 \pm 0.4^{b}$ & $7.4 \pm 0.5^{d}$ & $77.6 \pm 4.5^{\mathrm{a}}$ \\
\hline S. cerevisae & $12.6 \pm 0.3^{f}$ & $2.1 \pm 0.3^{\mathrm{a}}$ & $2.5 \pm 0.2^{b}$ & $8.0 \pm 0.2^{d}$ & $74.8 \pm 1.5^{\mathrm{a}}$ \\
\hline \multicolumn{6}{|c|}{ Medium-cyanide } \\
\hline $\begin{array}{l}\text { Unfermented } \\
\text { Fermented }\end{array}$ & $4.7 \pm 0.3^{\mathrm{a}}$ & $2.7 \pm 0.3^{\mathrm{c}}$ & $0.9 \pm 0.3^{a}$ & $1.1 \pm 0.3^{\mathrm{a}}$ & $90.6 \pm 1.5^{c}$ \\
\hline R. oryzae & $8.8 \pm 0.2^{\mathrm{C}}$ & $1.6 \pm 0.2^{\mathrm{a}}$ & $2.9 \pm 0.2^{b}$ & $4.5 \pm 0.4^{c}$ & $76.0 \pm 2.5^{\mathrm{a}}$ \\
\hline S. cerevisae & $9.6 \pm 0.3^{d}$ & $1.8 \pm 0.2^{\mathrm{a}}$ & $3.0 \pm 0.3^{b}$ & $5.0 \pm 0.3^{c}$ & $74.5 \pm 3.3^{\mathrm{a}}$ \\
\hline
\end{tabular}

Values represent means of triplicate.

Values with the same alphabet along the same column are not significantly different $(P>0.05)$.

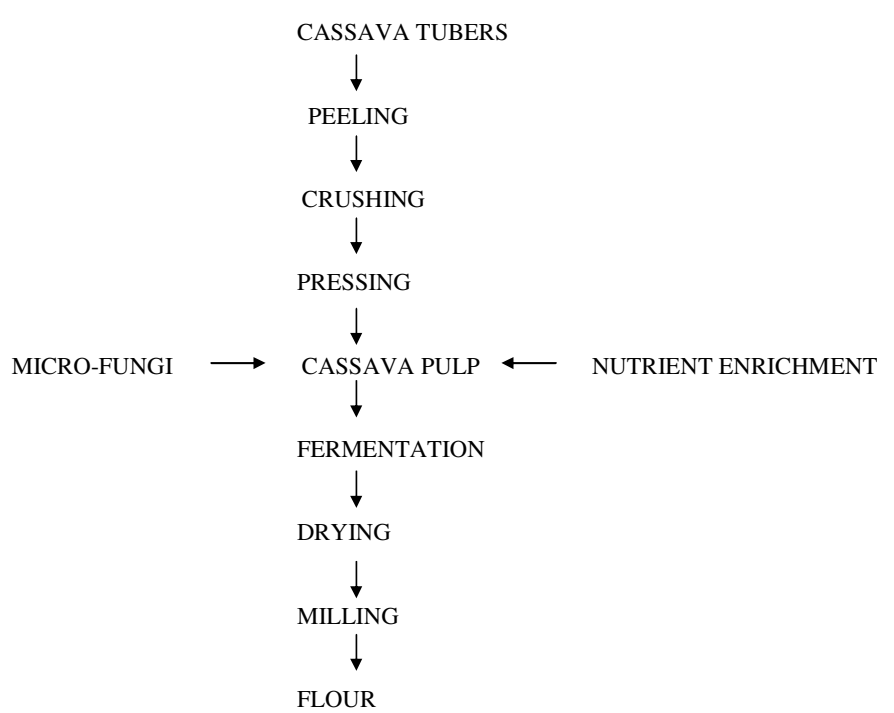

Figure 1. Production chart for micro-fungi fermented cassava flour.

(ANOVA) and the least significance difference (LSD) were carried out (Zar, 1984). Significance was accepted at $p \leq 0.05$.

\section{RESULTS AND DISCUSSION}

In view of the low protein content, lack of essential amino acids and high cyanide content of some cassava products, methods of upgrading the protein content of cassava and reducing the anti-nutrient content (cyanide, phytate and tannin) are being developed. Fortification with proteinous plants such as soyabeans and melon has been reported (Odetokun et al., 1998; Oshodi, 1988). However, solid media fermentation of cassava products with certain micro-fungi has the advantage of being able to increase the nutrient and reduce the anti-nutrient content. In this study, the ability of pure strain of $R$. oryzae and $S$. cerevisae to increase the nutrient and decrease the anti-nutrient content of cassava flour produced from low- and medium- cyanide variety of cassava tubers was investigated.

The results presented in Table 1 , revealed that unfermented cassava flour produced from low cyanide cassava tubers had a significantly higher $(P<0.05)$ proximate composition (\%) [protein (6.4), crude fibre (3.8), ash (1.4) and fat (2.9)] than those produced from medium cyanide cassava tubers [protein (4.7), crude fibre (2.7), ash (0.9) and fat (1.1)], except the carbohydrate content. The protein content of the flours were higher than that of some commonly consumed yam tubers, but within the same range with the wild yams in Nigeria (Akindahunsi and Oboh, 1998). Yam tubers are good carbohydrate source in Nigeria diet. However, the protein content of the cassava flour are far below that of some commonly consumed plant food in Nigeria such as legumes (Aletor and Aladetimi, 1989) and leafy vegetables (Aletor and Adeogun, 1995; Oboh, 2005a). However, the crude fibre, fat, ash and carbohydrate were within the same range with what Akindahunsi et al. (1999) and Oboh and Akindahunsi (2003) reported for cassava products (garri and flour) in Nigeria.

Furthermore, fermentation of the cassava flour with pure strain of either $R$. oryzae or $S$. cerevisae for three days caused a significant increase $(P<0.05)$ in the protein, ash and fat content. The increase in protein content agrees with earlier reports (Vlavonou, 1988; Raimbault, 1998; Akindahunsi et al., 1999) that fermentation of cassava with certain fungi such as $R$. oryzae $(10 \%)$ and Aspergillus niger (12\%) would increase the protein content of the cassava. The increase in the protein content of cassava flour may be because some of the microfungi, which degrade cassava pulp readily (Vlavonou, 1988; Reade and Gregory, 1975; Akindahunsi et al., 1999), could have secreted some extracellular enzymes (protein) in the cassava pulp (Lehninger, 1987; Akinda- 
Table2. Mineral composition of micro-fungi fermented cassava flour (ppm dry weight).

\begin{tabular}{|l|c|c|c|c|c|c|}
\hline \multicolumn{1}{|c|}{ Sample } & $\mathbf{F e}$ & $\mathbf{Z n}$ & $\mathbf{M g}$ & $\mathbf{N a}$ & $\mathbf{K}$ & $\mathbf{C a}$ \\
\hline Low-cyanide & $33.4 \pm 3.5^{\mathrm{a}}$ & $46.3 \pm 3.0^{\mathrm{a}}$ & $109.5 \pm 6.5^{\mathrm{a}}$ & $235.9 \pm 2.7^{\mathrm{b}}$ & $372.2 \pm 2.9^{\mathrm{b}}$ & $336.6 \pm 7.4^{\mathrm{b}}$ \\
\hline $\begin{array}{l}\text { Unfermented } \\
\text { Fermented }\end{array}$ & & & & & \\
R. oryzae & $37.0 \pm 2.4^{\mathrm{a}}$ & $46.9 \pm 3.8^{\mathrm{a}}$ & $305.2 \pm 8.2^{\mathrm{c}}$ & $238.6 \pm 1.2^{\mathrm{b}}$ & $503.3 \pm 3.7^{\mathrm{d}}$ & $345.3 \pm 5.1^{\mathrm{b}}$ \\
S. cerevisae & $40.1 \pm 3.8^{\mathrm{a}}$ & $49.4 \pm 2.7^{\mathrm{a}}$ & $310.1 \pm 8.3^{\mathrm{c}}$ & $234.6 \pm 2.1^{\mathrm{b}}$ & $506.1 \pm 5.5^{\mathrm{d}}$ & $337.8 \pm 6.5^{\mathrm{b}}$ \\
\hline Medium-cyanide & $49.8 \pm 4.7^{\mathrm{b}}$ & $56.5 \pm 2.5^{\mathrm{b}}$ & $238.9 \pm 5.7^{\mathrm{b}}$ & $215.3 \pm 3.9^{\mathrm{a}}$ & $265.4 \pm 1.8^{\mathrm{a}}$ & $294.0 \pm 3.1^{\mathrm{a}}$ \\
\hline $\begin{array}{l}\text { Unfermented } \\
\text { Fermented }\end{array}$ & & & & & \\
R. oryzae & $51.9 \pm 2.9^{\mathrm{b}}$ & $60.3 \pm 2.6^{\mathrm{b}}$ & $365.7 \pm 10.5^{\mathrm{d}}$ & $216.0 \pm 3.4^{\mathrm{a}}$ & $439.1 \pm 6.3^{\mathrm{c}}$ & $295.5 \pm 2.8^{\mathrm{a}}$ \\
S. cerevisae & $53.9 \pm 3.2^{\mathrm{b}}$ & $61.8 \pm 1.9^{\mathrm{b}}$ & $371.8 \pm 7.7^{\mathrm{d}}$ & $222.2 \pm 4.7^{\mathrm{a}}$ & $432.7 \pm 7.2^{\mathrm{c}}$ & $301.2 \pm 3.7^{\mathrm{a}}$ \\
\hline
\end{tabular}

Values represent means of triplicate.

Values with the same alphabet along the same column are not significantly different $(P>0.05)$.

hunsi et al., 1999; Okafor and Ejiofor, 1990). The increase in the microbial biomass in the form of single cell proteins may be another reason for the increase in the protein content (Okafor, 1998; Akindahunsi et al., 1999).

The increase in the fat content could be attributed to the possibility that, the fungi could secrete microbial oil (Oboh and Akindahunsi, 2003). This assertion agrees with earlier findings of Akindumila and Glatz (1998), to the extent that micro-organism could produce microbial oil during fermentation. It is also interesting to know that the fat content of the fermented cassava flour from low cyanide cassava variety was significantly higher $(\mathrm{P}<$ 0.05 ) than those produced from medium-cyanide cassava variety. The increase in the ash could be attributed to the inorganic content of nutrient solution, which contains both the salt of magnesium and potassium. However, there was no significant difference in the ash content of the fermented cassava flour from both the low- and mediumcyanide cassava tubers.

The results of the carbohydrate and crude fibre content of the cassava flour (Table 1) revealed that the carbohydrate content of the unfermented cassava flour from medium-cyanide cassava tuber was significantly higher $(P<0.05)$ than those produced from low cyanide cassava tubers, while the reverse is the case with crude fibre content. However, micro-fungi solid substrate fermentation of the cassava mash caused a significant decrease $(P<0.05)$ in the carbohydrate and crude fibre content of the flour produced from both the low-cyanide and medium-cyanide variety of cassava tubers. Conversely, there was no significant difference $(P>0.05)$ in the carbohydrate and crude fibre content of the fermented cassava flour from both varieties. The basis for the decrease in the crude fibre and carbohydrate of the fermented cassava flour from both varieties will not be far fetch from the possibility that the micro-fungi could secrete hydrolytic enzymes (Oboh et al., 2003; Oboh, 2005b). These enzymes are capable of hydrolyzing both the carbohydrate and crude fibre into simple sugars, which the organism could use as its carbon source and transform it to other macromolecules or metabolites such as protein and fat (Oboh and Akindahunsi, 2003; Oboh, 2006).

It is also obvious from the results that the level of increase in protein and fat content was significantly higher in cassava flour produced from low-cyanide cassava tuber than those produced from medium-cyanide cassava tubers. The reason for the significant difference in the level of increase in protein and fat content of the fermented cassava flour may not be far fetch from the possibility that the higher cyanide content in the medium - cyanide cassava could have inhibited the growth of the fungi. Thereby limited the amount of protein added to the flour in the form of single cell proteins, and this may have ultimately caused the lower protein content of the flour produced from medium-cyanide cassava tuber. In addition, this inhibition could have affected the metabolic activity of the fungi, in such a way that will reduces the amount of microbial oil secreted by the fungi into cassava flour.

Furthermore, the results in Table 1 also revealed that $S$. cerevisae was more efficient in bringing about an increase in both the protein and fat content of the cassava flour. These results agree with earlier reports by Akindahunsi et al. (1999) and Oboh and Akindahunsi (2003) in that $S$. cerevisae solid substrate fermented cassava had higher protein content than $R$. oryzae fermented cassava flour (Akindahunsi et al., 1999). One of the possible reasons for the ability of $S$. cerevisae to cause a higher increase in fat and protein could be that the culture condition favours the growth of $S$. cerevisae more than $R$. oryzae. In addition, it may be that $S$. cerevisae would tolerate the acidic environment and the pre- 
Table 3. Anti-nutrient composition of micro-fungi fermented cassava flour (dry weight).

\begin{tabular}{|l|c|c|c|}
\hline \multicolumn{1}{|c|}{ Sample } & Tannin (\%) & Cyanide (mg/kg) & Phytate (mg/100g) \\
\hline Low-cyanide & $0.4 \pm 0.0^{\mathrm{c}}$ & $10.9 \pm 0.3^{\mathrm{c}}$ & $339.5 \pm 8.0^{\mathrm{e}}$ \\
\hline Unfermented & & $3.4 \pm 0.4^{\mathrm{a}}$ & $112.8 \pm 5.2^{\mathrm{a}}$ \\
Fermented & $0.1 \pm 0.0^{\mathrm{a}}$ & $3.7 \pm 0.2^{\mathrm{a}}$ & $129.2 \pm 7.1^{\mathrm{b}}$ \\
R. oryzae & $0.1 \pm 0.0^{\mathrm{a}}$ & $24.5 \pm 0.2^{\mathrm{d}}$ & $451.3 \pm 7.5^{\mathrm{f}}$ \\
S. cerevisae & & \\
\hline Medium-cyanide & \\
\hline Unfermented & $0.4 \pm 0.0^{\mathrm{c}}$ & & \\
Fermented & & & \\
R. oryzae & $0.2 \pm 0.0^{\mathrm{b}}$ & $.4 \pm 0.6^{\mathrm{b}}$ & $225.6 \pm 4.2^{\mathrm{c}}$ \\
S. cerevisae & $0.2 \pm 0.0^{\mathrm{b}}$ & $9.4 \pm 0.5^{\mathrm{b}}$ & $282.1 \pm 5.3^{\mathrm{d}}$ \\
\hline
\end{tabular}

Values represent means of triplicate.

Values with the same alphabet along the same column are not significantly different $(\mathrm{P}$ $>0.05)$.

sence of cyanide than $R$. oryzae.

The results of the mineral composition of micro-fungi fermented cassava flour are presented in Table 2. The result revealed that unfermented cassava flour produced from medium-cyanide cassava tubers had significantly higher $(\mathrm{P}<0.05) \mathrm{Fe}, \mathrm{Zn}$ and $\mathrm{Mg}$. While $\mathrm{Na}, \mathrm{K}$ and $\mathrm{Ca}$ were higher in cassava flour produced from low-cyanide cassava tubers. However, the results are within the same range with the mineral composition of cassava products earlier reported (Oboh and Akindahunsi, 2003; Akindahunsi et al., 1999; Oboh et al., 2002). Micro-fungi fermentation of the cassava did not cause any significant change in the mineral composition of the cassava flour, except in magnesium and potassium where there was a significant increase $(P<0.05)$. The magnesium and potassium salts present in the nutrient solution could have caused this increase in $\mathrm{Mg}$ and $\mathrm{K}$ content.

The results of the anti-nutrient (phytate, tannin and cyanide) content of fungi fermented cassava flour produced from low- and medium-cyanide variety of cassava tubers are presented in Table 3 . Tannins affect nutritive value of food by forming a complex with protein (both substrate and enzyme) thereby inhibiting digestion and absorption (Aletor, 1993); they also impart dull colour on cassava products, and this affect the market value of the products. As presented in Table 3, there was no significant difference in the tannin content of cassava flour from both varieties. These values were within the range of tannin content of cassava tubers and products (Hahn, 1992; Akindahunsi et al., 1999; Oboh and Akindahunsi, 2003; Oboh et al., 2002). Micro-fungi fermentation of the cassava caused a significant decrease in the tannin content of the cassava flour; however, the level of decrease was significantly higher in flour from low-cyanide cassava tubers than those from medium cyanide cassava tubers, but there was no significant difference in the ability of the fungi to reduce the tannin content in the cassava tubers. However, both the fermen- ted and unfermented cassava flour from both varieties of cassava could be considered safe with regard to cyanide poisoning, since the tannin content is far below the detrimental dose of $0.7-0.9 \%$ (Aletor, 1993).

The results of the cyanide content of both the fermented and unfermented cassava flour from both the low-and medium-cyanide variety of cassava are also presented in Table 3. Cyanide is very poisonous because it binds cytochrome oxidase and stops its action in respiration, which is a key energy conversion process in the body. The lethal dose for an adult depends on body weight and is between 30 and $210 \mathrm{mg}$ of hydrogen cyanide. Sometimes persons eating a cassava meal exceed these limits and deaths occur due to cyanide poisoning. Smaller (non-fatal) amounts of cyanide cause acute intoxication with symptoms of dizziness, headache, stomach pains, vomiting and diarrhea (CCDN, 2006). The cyanide content of unfermented cassava flour from medium-cyanide variety was significantly higher $(\mathrm{P}<$ $0.05)$ than those produce from low-cyanide variety. This higher cyanide content in the cassava produced from medium-cyanide variety could be attributed to the fact that medium-cyanide variety has higher cyanide content than the low-cyanide variety.

However, fermentation of the cassava caused a significant decrease $(P<0.05)$ in the cyanide content of the cassava flour from both varieties of cassava. Moreover, there was no significant difference $(P>0.05)$ in the ability of the fungi to bring about the decrease. This shows that $R$. oryzae and $S$. cerevisae are capable of utilizing cyanogenic glycosides and the breakdown products, thus explaining why they are natural flora involved in cassava fermentation during garri processing (Akindahunsi et al., 1999; Oke, 1968). The cyanide content of both the unfermented and fermented cassava flour from both varieties of cassava is within the same range with the data earlier reported for some cassava products (Oboh and Akindahunsi, 2003; Akindahunsi et 
Table 4. Zn Bioavailability estimation in micro-fungi fermented cassava flour.

\begin{tabular}{|c|c|c|c|c|c|c|}
\hline Sample & [Phytate] $^{*}$ & {$[\mathrm{Zn}]^{*}$} & {$[\mathrm{Ca}]^{*}$} & [Phytate]/ [Zn] & [Ca]/[Phytate] & [Ca]x[Phytate]/[Zn] $]^{*}$ \\
\hline Low-cyanide & & & & & & \\
\hline Unfermented & $0.5 \times 10^{-2}$ & $7.1 \times 10^{-2}$ & $84.2 \times 10^{-2}$ & 0.07 & 168.4 & 0.06 \\
\hline R. oryzae & $0.2 \times 10^{-2}$ & $7.2 \times 10^{-2}$ & $88.8 \times 10^{-2}$ & 0.03 & 444.0 & 0.03 \\
\hline S. cerevisae & $0.2 \times 10^{-2}$ & $7.6 \times 10^{-2}$ & $85.7 \times 10^{-2}$ & 0.03 & 428.5 & 0.02 \\
\hline Medium-cyanide & & & & & & \\
\hline Unfermented & $0.7 \times 10^{-2}$ & $8.7 \times 10^{-2}$ & $66.0 \times 10^{-2}$ & 0.08 & 94.3 & 0.05 \\
\hline Fermented & & & & & & \\
\hline R. oryzae & $0.3 \times 10^{-2}$ & $9.3 \times 10^{-2}$ & $72.9 \times 10^{-2}$ & 0.03 & 243.0 & 0.02 \\
\hline S. cerevisae & $0.4 \times 10^{-2}$ & $9.5 \times 10^{-2}$ & $75.3 \times 10^{-2}$ & 0.04 & 188.3 & 0.03 \\
\hline
\end{tabular}

${ }^{*} \mathrm{~mol} / \mathrm{kg}$

al., 1999; Oboh et al., 2002). Moreover, the cyanide levels are far below the detrimental level of $30 \mathrm{mg} / \mathrm{kg}$ (Akinrele et al., 1962). These products could therefore be considered safe with regard to cyanide poisoning.

The phytate content of the fermented and unfermented cassava flour produced from low- and medium-cyanide cassava varieties are also presented in Table 3. Phytic acid is a common storage form of phosphorus in seeds and in a few tubers and fruits. However, it is also considered an anti-nutritional factor. The complexing of phytic acid with nutritionally essential elements and the possibility of interference with proteolytic digestion have been suggested as responsible for anti-nutritional activity (Ruales and Nair, 1993). The unfermented cassava flour from medium cyanide cassava tubers had a significantly higher $(p<0.05)$ phytate content than those produced from low-cyanide variety. However, micro-fungi fermentation of the cassava mash caused a significant decrease $(p<0.05)$ in the phytate content. However, S. cerevisae was more effective in reducing the phytate content of the cassava flour than $R$. oryzae.

The decrease in the phytate content of the fungi fermented cassava products could possibly be attributed to the secretion of the enzyme phytase by the fungi. This enzyme is capable of hydrolyzing phytate (Oboh et al., 2003), thereby decreasing the phytate content of the cassava products. The variation in the level of decrease in the phytate content of the products by each fungus indicates that the enzyme activity varies with the organism (Oboh et al., 2003). The phytate content of the fermented and unfermented cassava flour from both varieties of cassava are far below that of yam tubers (Akindahunsi and Oboh, 1998), fermented and unfermented legumes (Oboh, 2006b; 2006c), some leafy vegetables (Oboh et al., 2005; Oboh, 2005c).

Furthermore, the effect of the phytate content on the bioavailability of zinc was estimated as shown in Table 4. The calculated (Phytate)/(Ca) molar ratios for the fermented and unfermented cassava flour from both varieties were far below 15.0, which is considered as the critical value for reduced zinc bioavailability (Fergusson et al., 1988). In addition, the calculated (Ca)/(Phytate) molar ratios for the fermented and unfermented cassava flour from both varieties of cassava were far above 6.0. Wise (1983) has suggested that the solubility of phytate and proportion of zinc bound to the complex depend on the dietary $\mathrm{Ca}$ levels. In his model, phytate precipitation is not complete until dietary $\mathrm{Ca}$ : phytate molar ratios attain a value of approximately 6.0. At lower ratios, phytate precipitation is incomplete, causing some dietary zinc to remain in solution.

Calculated $(\mathrm{Ca})$ (phytate)/(Zn) molar ratio is a better index for predicting $\mathrm{Zn}$ bioavailability due to a kinetic synergism which exists between $(\mathrm{Ca})$ and $(\mathrm{Zn})$ ions resulting in a $\mathrm{Ca}: \mathrm{Zn}$ : phytate complex, which is less soluble than the phytate complex formed by either ion alone (Oberleas, 1973). The results clearly revealed that the calculated molar ratios for both the fermented and unfermented cassava flour from both varieties of cassava are far below $0.5 \mathrm{~mol} . \mathrm{kg}$, which is considered as the critical level for reduced $\mathrm{Zn}$ bioavailability (Davis and Warrington, 1986; Oboh et al., 2003). Although there was no reduced $\mathrm{Zn}$ bioavailability in the unfermented and fermented cassava but fermentation by each of the fungus caused a higher availability of dietary $\mathrm{Zn}$, as revealed by there lower calculated molar ratios. The higher bioavailability of $\mathrm{Zn}$ in the fermented cassava could be attributed to the reduced phytate content, since fermentation did not cause any significant change in either the $\mathrm{Zn}$ or Ca content.

\section{Conclusion}

It is obvious from this study that unfermented cassava flour from low-cyanide cassava variety has higher protein, crude fibre, ash, fat, $\mathrm{Na}, \mathrm{K}$ and $\mathrm{Ca}$ content, but lower antinutrient (phytate, cyanide and tannin) content. While that of medium-cyanide have higher carbohydrate, $\mathrm{Fe}, \mathrm{Zn}$ and $\mathrm{Mg}$ content. However, micro-fungi solid substrate fermentation of the cassava caused a significant increase in the 
protein, fat and $\mathrm{Zn}$ bioavailability, while it caused a significant decrease in the anti-nutrient content. However, low-cyanide cassava variety appears to support nutrient enrichment and anti-nutrient (toxicant) detoxification than the medium-cyanide variety. Furthermore, $S$. cerevisae appears to be more efficient in bringing about nutrient enrichment and detoxification of the cassava flour than $R$. oryzae.

\section{REFERENCES}

Achinewhu SC, Barber LI, ljeoma IO (1998). Physicochemical properties and garification (gari yield) of selected cassava cultivars in Rivers State, Nigeria. Plant Foods Hum. Nutr. 52(2): 133-140.

Adewusi SRA, Ojumu TV, Falade OS (1999). The effect of processing on total organic acids and mineral availability of simulated cassavavegetable diets. Plant Foods Hum. Nutr. 53: 367-380.

Akindahunsi AA, Oboh G (1998). Chemical studies on two tropical wild yams Dioscorea bulbifera and Dioscorea manganotiana. La Rivista Italiana Delle Sostanze Grasse, 75: 511-514.

Akindahunsi AA, Oboh G, Oshodi AA (1999). Effect of fermenting cassava with Rhizopus oryzae on the chemical Composition of its flour and gari. La Rivista Italiana Delle Sostanze Grasse, 76: 437440.

Akindumila F, Glatz BA (1998). Growth and oil production of Apiotrichum curvatum in tomato juice. J. Food Prot. 61(11): 15151517.

Akinrele IA, Cook AS, Holgate RA (1962). The manufacture of gari from cassava in Nigeria. In Proceeding of 1st International Congress of Food Technology (pp. 633-644) London.

Aletor VA (1993). Allelochemicals in plant food and feedingstuffs: 1. Nutritional, biochemical and physiopathological aspects in animal production. Vet. Hum. Toxicol. 35(1): 57-67.

Aletor VA, Adeogun OA (1995). Nutrient and anti-nutrient components of some tropical leafy vegetables. Food Chem. 53: 375-379.

Aletor VA, Aladetimi OO (1989). Compositional evaluation of some cowpea varieties and some under utilized edible legumes in Nigeria. Die Nahrung, 33: 999-1007.

Amutha R, Gunasekaran P (2001). Production of ethanol from liquefied cassava starch using co-immobilized cells of Zymomonas mobilis and Saccharomyces diastaticus. J. Biosci. Bioeng. 92(6): 560-564.

AOAC (1990). Official methods of Analysis (15 $\left.5^{\text {th }} \mathrm{ed}\right)$. Association of Official Analytical Chemists, Arlington, VA pp 125-126, 132, 877-878.

CCDN (2006). Cassava Cyanide Diseases Network (CCDN): http://www.anu.edu.au/BoZo/CCDN/two.html

Collins JL, Falasinnu GA (1977). Yam (Dioscorea spp) flour fortification with soy flour. J. Food Sci. 42: 821-823.

De Bruijn GH (1971). A study of the cyanogenic character of cassava. Mededelingen Lanbouwhoge School Wageningen, 71(13): 1-140.

Davis NT, Warrington S (1986). The phytic acid mineral, trace element, protein and moisture content of UK Asian immigrant foods. Hum. Nutr. Appl. Nutr. 40A: 49-59.

Fergusson EL, Gibson RS, Lilian UT, Ounpuu S, Berry M (1988). Phytate, zinc and calcium contents of 30 East African foods and their calculated phytate: Zn, Ca: phytate and [Ca] [phytate]/[Zn] molar ratios. J. Food Compost. Anal. 1: 316-325.

Hahn SK (1992). Cyanide and tannin, traditional processing and utilization of cassava in Africa. International Institute for Tropical Agriculture (IITA).

Lehninger AL (1987). Bioenergetics and Metabolism, Principle of Biochemistry, 2nd Preprint, CBS Publisher and Distribution, pp. 313356.

Makkar HPS, Blummel M, Bowwy NK, Becken K (1993). Determination of tannins and their correlation with chemical and protein precipitation method. J. Sci. Food Agric. 61: 161-185.

Motarjemi Y (2002). Impact of small scale fermentation technology on food safety in developing countries. Int. J. Food Microbiol. 75(3): 213229.
Oberleas D (1973) Phytates. In: Toxicants Occuring Naturally in Foods. Washington DC: National Academic of Sciences, pp. 363-371.

Oboh G (2005a). Nutritional and safety evaluation of some tropical green leafy vegetables. J. Food Technol. 3(3): 389-392.

Oboh G (2005b). Isolation and characterization of amylase from fermented cassava (Manihot esculenta Crantz) wastewater, Afr. J. Biotechnol. 4(10): 1117-1123.

Oboh G (2005c). Effect of Some Post-Harvest Treatments on the Nutritional Properties of Cnidoscolus acontifolus Leaf. Pakistan J. Nutr. 4(4): 226-230

Oboh G (2006a). Nutrient enrichment of cassava peels using Saccharomyces cerevisae \& Lactobacillus spp solid media fermentation techniques. Electron. J. Biotechnol. 9 (1) (http://www.ejbiotechnology.info/content/vol9/issue1/full/1/)

Oboh G (2006b). Antioxidant properties of some commonly consumed $\&$ underutilized tropical legumes. Eur. Food Res. Technol. (In press).

Oboh G (2006c). Nutrient and anti-nutrient composition of condiments produced from some fermented underutilized legumes. J. Food Biochem. (In press).

Oboh G, Ekperigin MM, Kazeem Ml (2005). Nutritional and haemolytic property of Egg plant (Solanum macrocarpon) leaves. J. Food Compost. Anal. 18: 153-160

Oboh G, Akindahunsi AA, Oshodi AA (2002). Nutrient and Anti-nutrient content of Aspergillus niger fermented Cassava Products (flour \& gari). J. Food Compost. Anal. 15(5): 617-622.

Oboh G, Akindahunsi AA (2003). Biochemical changes in Cassava products (flour \& gari) subjected to Saccharomyces cerevisae solid media fermentation. Food Chem. 82(4): 599-602.

Oboh G, Akindahunsi AA, Oshodi AA (2003). Dynamics of Phytate-Zn balance of fungi fermented cassava products (Flour \& Gari). Plants Food Hum. Nutr. 58: 1-7.

O'Brien GM, Taylor AJ, Poulter NH (1991). Improved enzymatic assay for cyanogens in fresh and processed cassava. J. Sci. Food Agric. 56: 277-289.

Odetokun SM, Aiyesanmi FA, Esuoso KO (1998). Enhancement of nutritive value of pupuru, a fermented cassava product. La Rivista Italiana Delle Sostanze Grasse, 75: 155-158.

Okafor N (1998). An Integrated Bio-system for the Disposal of Cassava Wastes, Integrated Bio-Systems in Zero Emissions Applications, Proceedings of the internet Conference on integrated Bio-Systems http://www.ias.unu.edu/proceedings/icibs

Okafor N, Ejiofor AO (1990): Rapid detoxification of cassava mash by a yeast simultaneously producing linamarase and Amylase. Process Biochem. 25: 82-86.

Oke OL (1968). Cassava as food in Nigeria. World Rev. Nutr. Diet. 9: 227-250.

Onwueme IC (1978). The tropical tuber crops. UK: John Wiley and Sons Ltd. pp. 167-195.

Oshodi AA (1988). Protein enrichment of foods that are protein deficient II: Fortification of processed cassava (Gari) with bovine blood plasma protein concentrate. Niger. J. Appl. Sci. 6(1): 61-64.

Perkin-Elmer (1982). Analytical methods for atomic absorption spectrophotometry. USA: Perkin-Elmer Corp.

Raimbault M (1998). General and microbiological aspects of solid substrate fermentation, Electron. J. Biotechnol. 1(3) : http://www.ejbiotechnology.info/content/vol1/issue3/full/9/9.PDF.

Reade AE, Gregory KF (1975). High temperature protein enriched feed from cassava fungi. Appl. Microbiol. 30: 897-907.

Ruales J, Nair BM (1993). Saponins, phytic acid, tannins and protease inhibitors in quinoa (Chenopodium quinoa, Willd) seeds. Food Chem. 48: 137-143.

Santos N, Gomez G (1977). Pilot plant for single-cell protein production in cassava as animal feed. In: Nestel, B.Y.,Graham, M., (Eds.), Proceedings of a workshop held at the University of Guelph. Ottawa: IDRC, p. 914.

Vlavonou BM (1988). Cassava processing technologies in Africa. In Natalie D. Hahn(Ed.), Praise of cassava (pp. 25-32). Int. Inst. Trop. Agric. (IITA).

Wheeler EL, Ferrel RE (1971). A method for phytic acid determination in wheat fractions. Cereal Chem., 48: 312-316.

Wise A (1983). Dietary factors determining the biological activities of 
phytate. Nutrition Abstract Review/Review of Clinical Nutrition, 53: 791-806.

Zar JH (1984). Biostatistical Analysis, Prentice-Hall, Upper Saddle River, NJ. p. 620. 